110

\title{
ビール貯酒タンク模型を用いた研究
}

高本雄治○ (サッポロビール〔株〕), 齋藤善雄 (東邦大学), 河西勝興 (サッポロビール〔株〕)

\section{A study on cooling process of water in small lagertank}

\section{Yuji TAKAMOTO, Yoshio SAITO, and Katsuoki KAWANISHI}

\section{ABSTRACT}

We have used lagertanks in the storage process of beer, and the shape of lagertank is cylindro-conical. The outer wall of the tank is cooled for maturing beer during the storage process with experienced control system. However the cooling process in the tank is hardly known, so we have studied the cooling process with cylindro-conical mini-tank. Here we report the cooling process based on the visualization and the measurement of temperature in the tank.

\section{Keywords: Visualization, Cylindro-conical tank, Cooling}

\section{1. 緒言}

貯酒工程はビールを熟成させることを目的としたビー ル製造工程の一つである。そこでは一般にシリンドロコ ニカル型タンク（円柱の下端が円錐状のタンク）が用い られている。そのタンクの外壁は泠却制御され、タンク 内のビール温度を管理することによりビールを熟成させ る。従って、タンク内の冷却過程を知ることは、ビール 熟成にとって重要であるが、実際のシリンドロコニカル 型タンクは規模が大きいため、タンク内のビールの冷却 過程を詳細に知ることは困難である。そこで、我々は夕 ンク内の椧却過程を調べる第一歩として、シリンドロコ ニカル型ミニタンクを用い、タンク外壁冷却時における ミニタンク内の水の様子を墨流し等の方法を用いて検討 したので報告する。

\section{2. 実㰸}

\section{1 村料}

（1）シリンドロコニカル型ミニタンク

$$
\text { シリンドロコニカル型ミニタンク（以下ミニタンク） }
$$

の模式図を図 1 に示す。可視化のため材質は透明なアク
リルとした。ミニタンクの内径は $100 \mathrm{~mm}$ 高さは $600 \mathrm{~mm}$ と し、コーン部の先端の角度は 60 度とした。円柱状の容器 （内径 $140 \mathrm{~mm}$ 、高さ $700 \mathrm{~mm}$ ）を準備し、タンク全体をその 円柱容器に入れ、円柱容器に $0 \sim 3{ }^{\circ} \mathrm{C}$ のプロピレングリコ 一ルを含む水（冷媒）を循環注入してタンク外壁を冷却 した。

\section{（2）ミニタンク内の水量および初期温度}

ミニタンク内に注入する水量は、直径と水蒿の比が 1 : 4 （水量 $2250 \mathrm{~m} \mathrm{~L}$ ) となるように調製した。初期水温は 約 $10^{\circ} \mathrm{C}$ とた。

\section{2 方法}

\section{（1）墨流し法による可視化}

冷媒で適当な時間冷却し、ピペットを用いて墨汁を䄪 $80 \mu \mathrm{L}$ をミニタンク壁際もしくは水面中心より注入した 後、墨汁の流れる様子を 3 台の CCD カメラにより撮影し た（図 2)。

\section{（3）ミニタンク内の水温測定}

ミニタンク内の水温を熱電対温度センサーを用いて測 
定した。センサーは図 3 に示す位置に配置し、各点の温 度を 1 秒間隔で計測した。

\section{3. 結果および考察}

\section{1 墨流し法によるミニタンク内の流れの可視化}

墨计をミニタンク内に注入したときの例を図 4 に示し た。その結果、冷却初期に底に生じた流れが徐々に成長 し、水面まで達することが分かった。

\section{2 水温測定}

図 5 に温度センサーによる各点での温度変化の様子を 示した。No. 1 センサー(タンクの底) の測定温度は、指 数関数的に減少する。No. 2 センサーの位置から順次、上 方に向かって水温が下がり、最後に水面の中心付近の水 温が下がる。No.1センサー以外の水温は、最初なだらか に減少し、その後急激に減少する。これは水の密度が約 $4{ }^{\circ} \mathrm{C}$ が最高で $4{ }^{\circ} \mathrm{C}$ を境に密度が下がり、その密度が下が った水が上昇することにより急激な温度下降が生じたと 考えられる。

それぞれのセンサー番号を横軸に取り、各センサーが $5{ }^{\circ} \mathrm{C}$ を示すまでの時間を図 5 から求め、その時間を綐軸 に取ったのが図6である。No.1センサーの位置を0とし て各センサーの鉛直方向の距離から、流れの平均速度を 推定するとコーン部を含む部分では $0.31 \mathrm{~mm} / \mathrm{s} 、 円$ 柱部分 では $0.34 \mathrm{~mm} / \mathrm{s}$ であった。(No. 1 センサーと No. 2 センサ 一の鉛直距離は $136 \mathrm{~mm}$ 、その他のセンサー間の距離は $50 \mathrm{~mm}$ である。)

\section{4. まとめ}

墨流し法による可視化と水温測定の結果を総合すると、 以下の冷却過程が推察される。

(1) 壁面で泠却された水は、 $4^{\circ} \mathrm{C} に$ 近づくことにより密 度が高くなり壁際を急落下する。

(2) コーン部底の温度は上から下降してくる水により急 速に下がる（図 5 の No.1 センサー参照)。

(3) コーン部の底付近にある下降してきた水は、さらに
冷却され $4{ }^{9}$ C以下となる。その結果、水の密度が小 さくなることにより浮力が生じ、コーン壁面に沿っ て上昇し始める。

(4)この結果、円筒壁面を下降する密度の高い水とコー ン壁面を上昇する密度の低い水が衝突する（図 4 参 照。

(5) 衝突した水は、タンク中心付近へ向から流れを形成 する。

(6) タンクの中心に向かった流れは、中心付近で下方お よび上方に向かい、2つの対流が形成される。

(7) 下方に形成された対流は徐々に成長し、上方の対流 を押し上げ表面に達する。

（8）最終的に壁面では上昇流、中心は下降流の大きな対 流ができる。

以上の結果、墨流しによる可視化およびミニタンク内 の水温測定によりシリンドロコニカル型ミニタンク内の 冷却過程が明らかにされた。現在、ここで用いたタンク とほぼ同じ容量の円柱型タンクおよび先端が半球のタン クの冷却について検討しているが定性的にはほほ同様な 結果が得られている。

\section{参考文献}

1) Unterstein,K.:Zylindrokonische Gartanks, Brauwelt,Nr27(1992),pp.1280-1286 


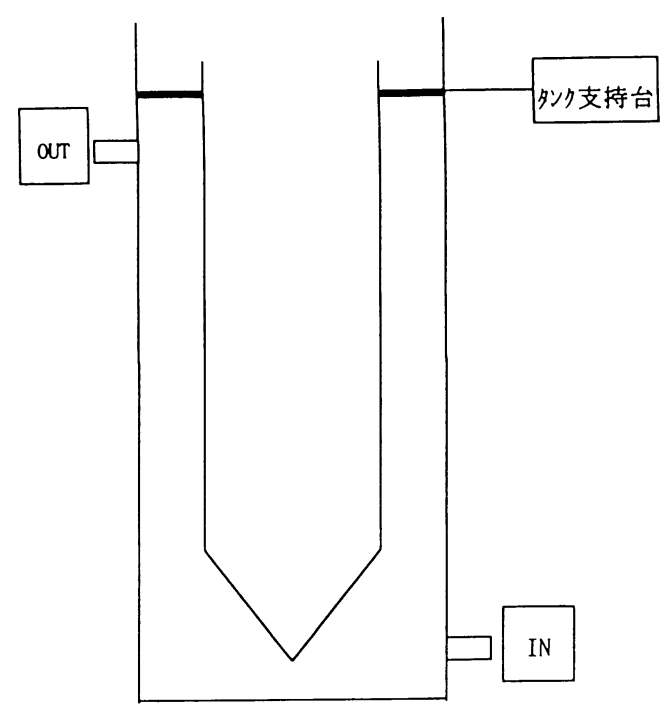

图 1 タンク模式図 (IN と OUT は冷媒の出入ロ )

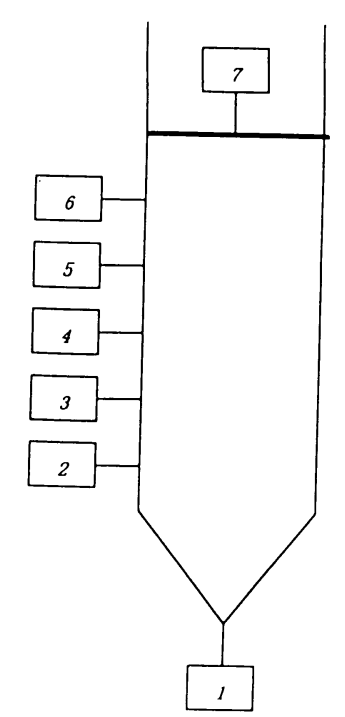

图 3 タンクの温度センサー位置 各番号は温度測定点

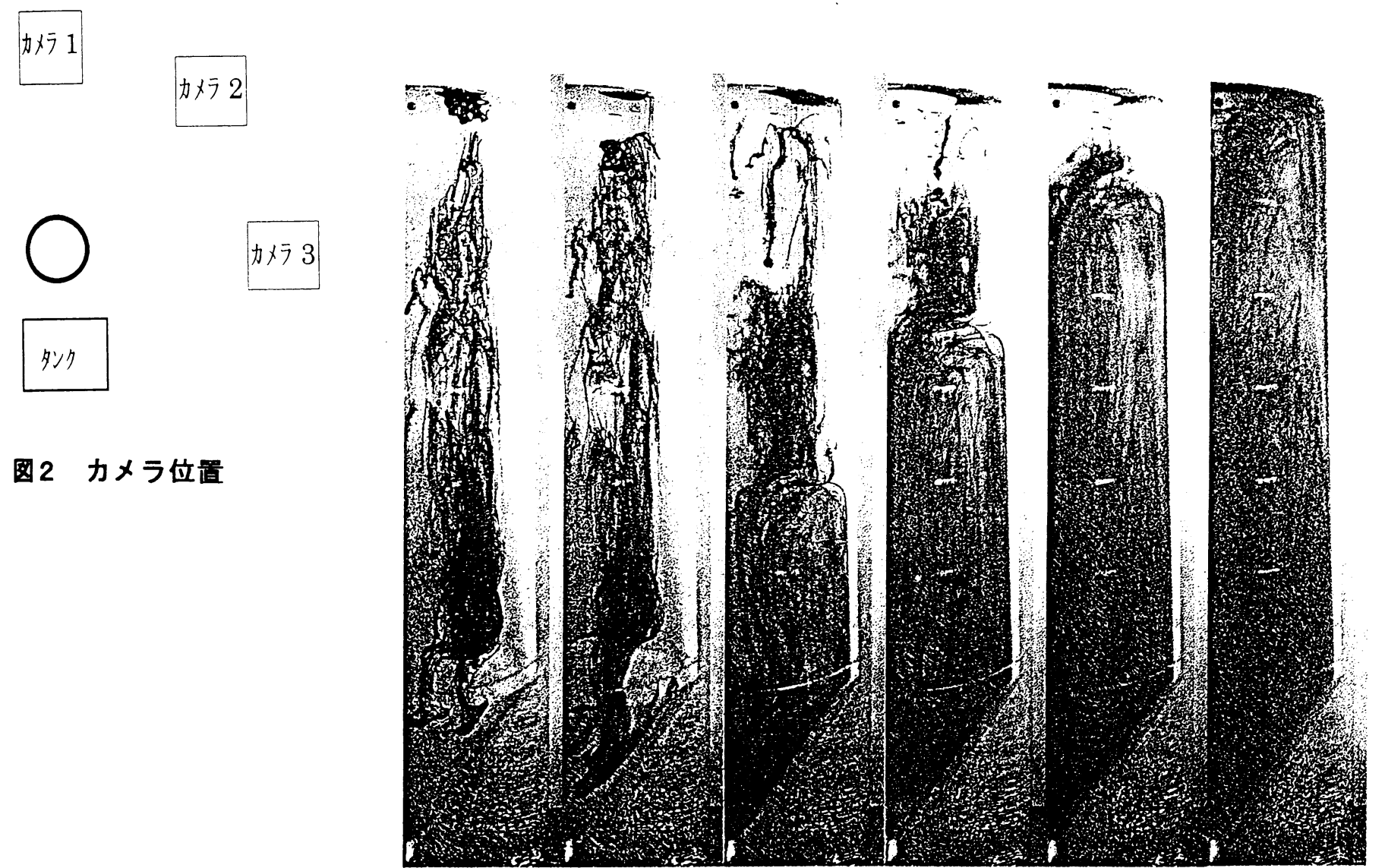

图 4直经と水蓠の比が 1:4の流れの例 


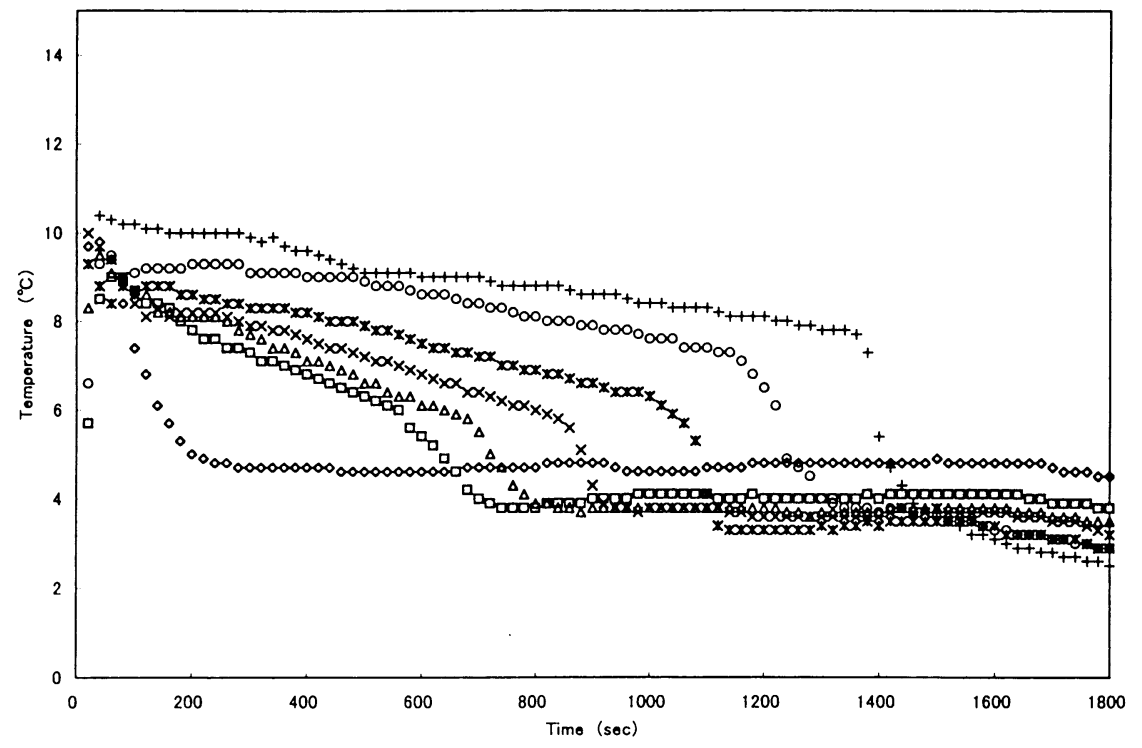

图 5 タンク内の温度測定

（センサ一番号は图 3 と対応）

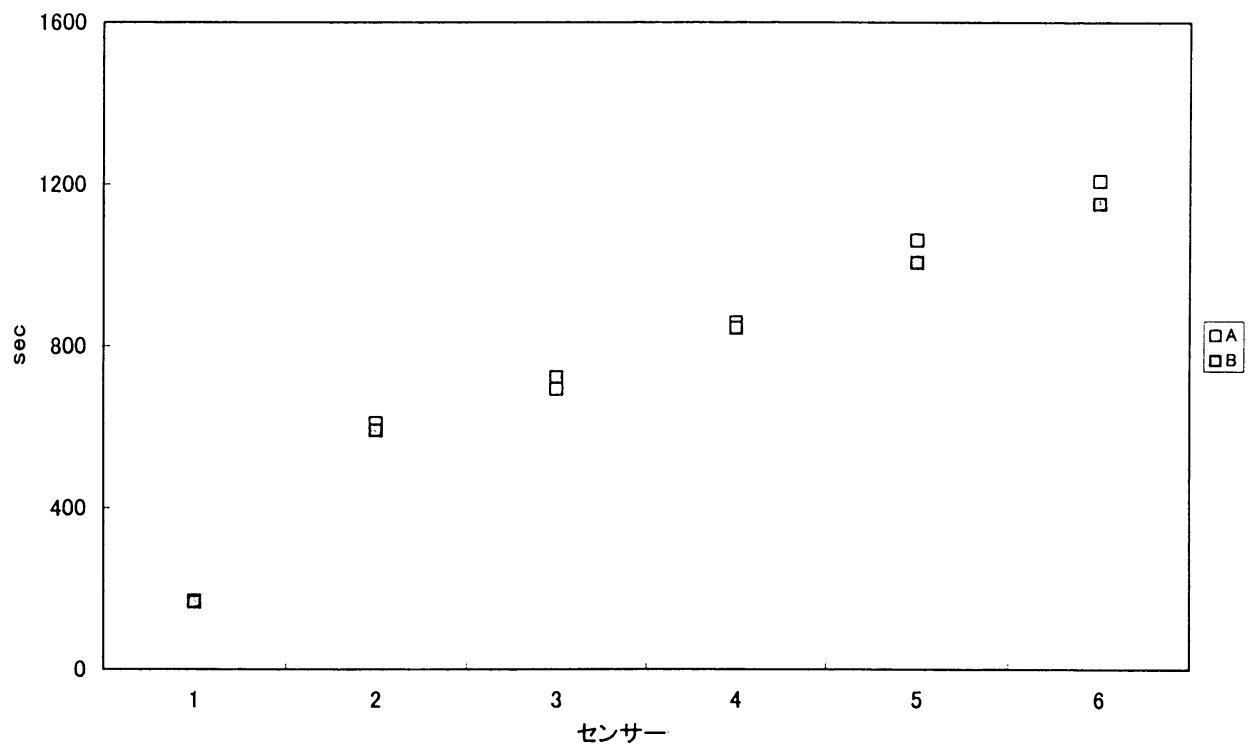

图 6 それぞれのセンサ一位且における水温が

$5{ }^{\circ} \mathrm{C}$ となるまでの時間

(A: 1 回目、B : 2 回目) 